\title{
Political Stability and FDI in OIC Countries
}

\author{
*Ahmad Jafari ${ }^{1}$ Samimi ${ }^{1}$, Maryam Monfared ${ }^{1}$, Reza Moghaddasi², Khosro Azizi $^{1}$ \\ ${ }^{1}$ Islamic Azad University, Firoozkuh Branch, Firoozkuh, Iran \\ ${ }^{2}$ Science and Research Branch, Islamic Azad University, Tehran, Iran \\ *jafarisa@yahoo.com
}

\begin{abstract}
The purpose of the present paper is to investigate the impact of Political stability on foreign direct investment (FDI) revenues in Organization of Islamic Conference (OIC) countries. To do so, we have concentrated on a sample of 16 countries for which the necessary data were available for the period 2002-2009. We have used a panel data regression analysis. Our empirical results indicate that Population, openness and gross domestic product (GDP) have positive impact on FDI, whereas Political Stability has a detrimental effect on FDI in OIC countries.
\end{abstract}

Keywords: Foreign Direct Investment (FDI), Political Stability, OIC countries, Panel data regression.

\section{Introduction}

Foreign direct investment as an important factor in accelerating economic growth in developing countries has been proved completely. Foreign direct investment to the host country, which gives the ability to invest beyond the level of domestic savings to achieve. Benefits of foreign direct investment are attracting capital, technology, knowledge, improving management capacity, increasing employment, improving competitiveness and increasing balance of payments. One of the most important factors attracting foreign direct investment is the security and low country risk both economic as well as non-economic factors such as political instability.

Stability of political regimes is referred to as the longevity of ruling authority in a country that ruling authority may be a single party in a one party dominant system or in an authoritarian regime or under military rule or a single party or a coalition of some parties in a multi party political system but the important thing is that it rules the country for a long period without any major political upheaval or turmoil. In economics, the phrase 'stability of political regimes' is used differently than in political science. Economics is not concerned whether the regime is a democracy or a dictatorship. Investors believe political instability in the host country is important for choosing investment locations and deciding the investment amount. Political instability is regarded by economists as a serious malaise harmful to economic performance. Political instability is likely to shorten policymakers' horizons leading to suboptimal short term macroeconomic policies. It may also lead to a more frequent switch of policies, creating volatility and thus, negatively affecting macroeconomic performance.

Considering its damaging repercussions on economic performance the extent at which political instability is pervasive across countries and time is quite surprising. Political instability as measured by Cabinet Changes, that is, the number of times in a year in which a new premier is named and/or 50 percent or more of the cabinet posts are occupied by new ministers, is indeed globally widespread displaying remarkable regional differences, whether the regime is democratic, dictatorship or soft Political uncertainty, no doubt, is an investor's nightmare. It does disturb the flow of foreign direct investment plans both into the private sector as well as the government owned public sector units and that surely affects economic growth .However, this argument is good only to a limited extent. Political stability is not necessarily an essential pre-requisite item for good economic growth. In real World, it is the other way around as it can be argued, that it is good economic growth, which essentially leads to political stability. This paper concentrates on the relationship between Political Stability and Foreign direct Investment in a sample of 16 OIC counties for the period 2002-2009.

\section{Empirical Studies}

Political instability hinders economic development through its effect on the accumulation of physical and human capital. Investments are often difficult to reverse, which means that investors will postpone new capital projects until the policy environment clarifies. In this section, we concentrate on recent major 
studies regarding the relationship between Political Stability and FDI. However, the main conclusion of most studies supported the negative impact of Political Stability on FDI. Kobrin (1979) concluded that the empirical evidence is inconsistent and mixed regarding the effect of political instability on FDI stocks or flows. Later econometrics studies continued to produce mixed finding. For example, Schneider and Frey (1985) found that political instability had a negative effect on FDI flows. Fatehi and Safizadeh (1989) failed to find statistical association between political stability and FDI. In a cross sectional analysis of FDI flows to 36 countries for 1977 and 1982. Barro (1995) found that political instability negatively affects economic growth and investment and argued that property rights are not enforced in politically unstable environments. He found that measures of political instability, such as coups, revolutions, and political assassinations, are inversely correlated with the growth of gross domestic product (GDP) and investment share of the GDP. He concluded that political instability, through its adverse effect on property rights, reduces growth and investment.

Alesina \& Perotti (1996) showed that political instability had a negative effect on investment in a sample of 70 countries from 1960 to 1985 . Using data for all reported manufacturing plant openings from 1984 to 1987, Woodward and Rolfe (1993) find that political stability increases the probability a country is selected as an investment location. In a cross sectional analysis of FDI flows to 36 countries for 1977 and 1982, Loree and Guisinger (1995) showed that political stability significantly promotes FDI inflows in 1982, but not in 1977. Alesina et al., (1996), in a sample of 113 countries from 1950 to 1982, analyze the joint determination of political instability and per capita GDP growth and find that instability has a negative and significant effect on growth rates. Globerman and Shapiro (2003) conducted a two stage analysis of FDI inflows of US to 143 countries during 1994 - 1997, in which the first stage investigates the causal factors of the probability that a country is an FDI recipient while the second stage examines the determinants of the amount of FDI received. They found that an index of political instability and violence, including armed conflict, social unrest, terrorist threats, etc, did not influence the probability whether a country received any FDI inflow, but reduced the amount of FDI inflow to a country. Li (2005) found a new theory that explains how political violence, an extreme form of political instability, affected foreign direct investment.

Jakobsen and de Soysa (2006) examined the same issue, and found that such a negative relationship between democracy and FDI is fully dependent on sample size and estimation methodology. Their results supported a strong positive relationship between democracy and FDI inflows to emerging countries. Amitendu and Shounkie (2007) concluded that, political stability is found to be negatively significant and confirms our hypothesis that politically unstable countries are unlikely to be attractive destinations for FDI. Busse and Hefeker (2007) showed that government stability, absence of internal conflict, and basic democratic rights are significant determinants of foreign direct investment inflows. Sarisoy and Manzocchi (2008) indicated that democracy is statistically significant and positive, and this can be interpreted as evidence that democracies may attract more FDI also through a higher rate of TFP and higher returns on investment, once political risk is controlled for.

Younis et al., (2008) Found that Political stability is playing an important role in determining economic growth in Asian economies. There is direct and indirect relationship between political stability and economic growth Political stability effects economic growth not only indirectly by sources of capital accumulation but also directly on growth than labor, human capital and economic freedom in Asia. In a quantitative approach, Political stability is playing a predominant role in determination of economic growth directly and indirectly in selected Asian economies. Jafari et al., (2010) concluded that political stability had a positive and significance impact on FDI in the MENA region. Biglaiser and Brown (2009) assessed the effect of political stability on foreign direct investment (FDI) in Latin America found that stable developing countries are not more likely to attract FDI inflows. Instead, economic reforms including domestic financial liberalization, trade opening, and privatization enhance foreign investor interest.

\section{Model, data, and estimation methodology:}

This article employs panel data for 16 countries over the period 2002-2009. All countries (OIC) for which data are available over this period are included in this study. In our study, we will use of panel data methods to estimate data. The FDI data is in terms of USA dollars and obtained from the World Bank's World Development Indicators (WDI, 2010). Our independent data include Openness of the economy (computed as export plus import as a share of GDP), and GDP come from the World Bank's World 
Development Indicators (WDI 2010). Comparison of these data in table (1) indicates that measure of average GDP, average Openness and FDI in OIC countries. The dependent variable is FDI per capita inflows. The key explanatory variable is the political stability level in the host country as measured by the International Country Risk Guide (ICRG) Governance index. Comparison of Political Stability and Average of some Variables in table (1) \& (2) shows that Kazakhstan has Political Stability than other selected countries. As can be seen some recent and potential members have relatively bad scores. As it shown in Table (2) \& Fig (1) the average of Foreign Direct Investment and GDP in Turkey is more than the other countries.

\section{Table: 1 Average of Political Stability in Selected OIC Countries}

\begin{tabular}{lc}
\hline \multicolumn{1}{c}{ Country } & score \\
\hline Albania & -0.40 \\
Algeria & -1.31 \\
Bangladesh & -1.32 \\
Cote & 2.06 \\
Egypt & -0.72 \\
Iran & -1.12 \\
Jordan & -0.32 \\
Kazakhstan & 0.32 \\
Morocco & -0.38 \\
Nigeria & -1.85 \\
Pakistan & -2.06 \\
Senegal & -0.19 \\
Thailand & -0.56 \\
Tunisia & 0.19 \\
Turkey & -0.73 \\
Uganda & -1.27
\end{tabular}

Source: The Worldwide Governance Indicators (2010)

Table.2. Average of Variables in Selected OIC countries

\begin{tabular}{ccc}
\hline Country & $\begin{array}{c}\text { Average of Foreign Direct } \\
\text { Investment (current } \mathbf{\$} \$ \text { ) }\end{array}$ & $\begin{array}{c}\text { Average of GDP Per Capita } \\
\text { (Constant 2000 US \$) }\end{array}$ \\
\hline Albania & 477420260.62 & 314.50 \\
Algeria & 1576437500.00 & 2082.78 \\
Bangladesh & 577093394.06 & 414.47 \\
Cote & 318192528.18 & 541.46 \\
Egypt & 5667537500.00 & 1611.80 \\
Iran & 2537697375.00 & 314.50 \\
Jordan & 1885134136.83 & 2192.06 \\
Kazakhstan & 7073551154.10 & 2032.12 \\
Morocco & 1800988082.32 & 1577.72 \\
Nigeria & 4608495416.41 & 444.43 \\
Pakistan & 2795500000.00 & 606.80 \\
Senegal & 210432134.47 & 514.94 \\
Thailand & 7096722004.28 & 2405.45 \\
Tunisia & 1476403718.52 & 2476.41 \\
Turkey & 10493750000.00 & 4612.75 \\
Uganda & 478905481.51 & 314.50 \\
\hline
\end{tabular}

Source: World Development Indicators (2010)

Figure (1) shows the Average of Foreign direct investment in 16 OIC countries during the years 20022009. As it is seen Turkey, Thailand and Kazakhstan have the highest average measures whereas Senegal and Cote have the lowest. 
Fig.1. Average FDI in selected OIC countries 2002-2009 (US\$)

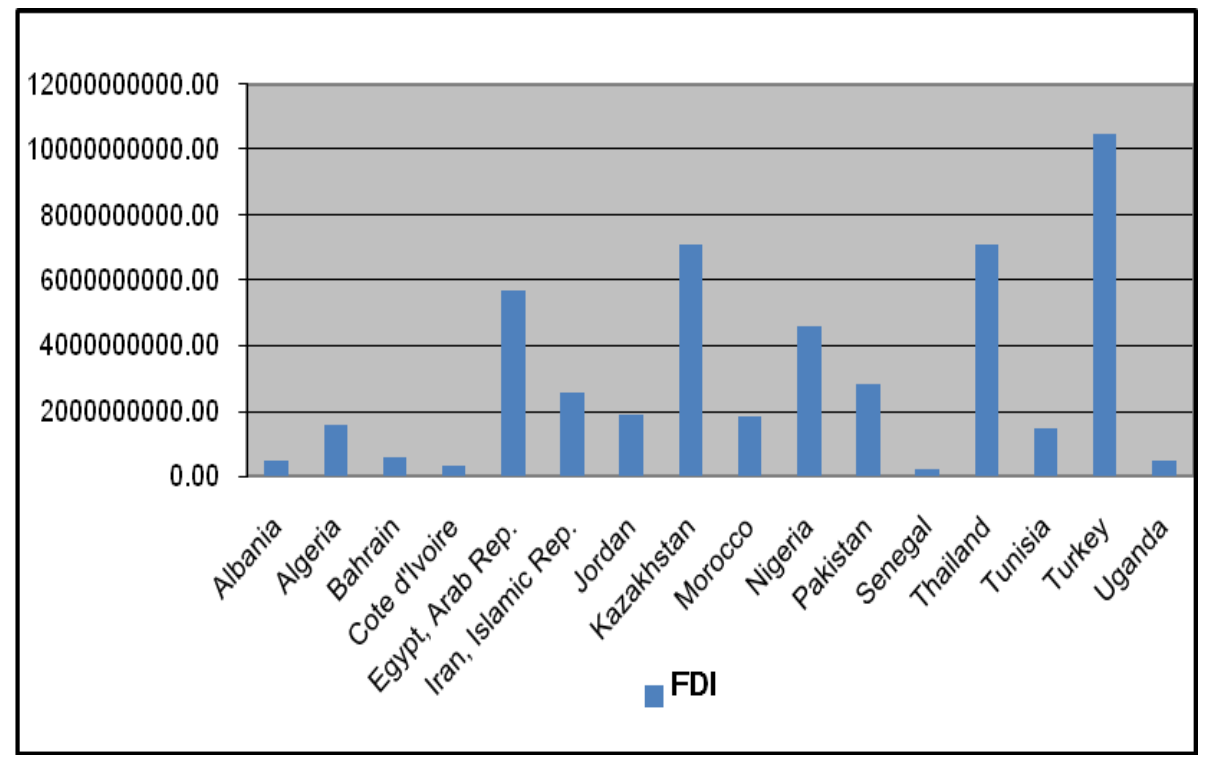

Source: UNCTAD(2010)

With panel data use, the sample size is much larger than would be the case if just pure time-series or cross-sectional data were employed, and so more degrees of freedom and more efficiency results in an increase in the reliability of the estimates of the regression coefficients (Baltagi, 2008).

First we test heterogeneous between units by F-statistic. If null hypothesis is not accepted, we use panel

The regression equation used to estimate the above model is as follows:

$$
\log F D I_{i, t}=\beta_{0}+\beta_{1} \log (G D P)_{i, t}+\beta_{2} \log (\mathrm{POP})_{i_{,} \mathrm{t}}+\beta_{3}(\text { OPENNESS })_{i_{2},}+\beta_{4}(P S)_{i, t}+\varepsilon_{i, t}
$$

\section{Results}

The estimation results using Eviews 6 are shown in table (3). As seen from Table (3), GDP, Population and Openness have positive and significance impact on FDI and the Political Stability has a negative effect on FDI inflows.

$H_{0^{n} \mu_{1}}=\mu_{2}=\cdots=\mu_{n 3}=0$

$H_{0} \neq H_{1}$

$F=\frac{\frac{(R R S S-U R S S)}{(N-1)}}{\frac{U R S S}{\left(N T_{-} N \_K\right)}} \sim F\left[(N-1) \cdot\left(N T_{\mathbb{N}_{K}}\right)\right]$

RRSS: Restrict Residual sum Squares

URSS: Unrestricted Residual sum Squares

$\mathrm{N}=$ numbers of units

$\mathrm{K}=$ numbers of Parameters

Then for choice between Fixed Effect (F.E) and Random Effect (R.E) models we used Hausman Test:

$H=\left(b_{s}-B_{s}\right)\left(M_{1}-M_{0}\right)-1\left(b_{s}-B_{s}\right) \cdot x_{2}(r)$ 
$\mathrm{r}=$ number of parameters.

$\mathrm{M}_{1}=$ covariance matrix for coefficients of F.E model $\left(b_{s}\right)$.

$\mathrm{M}_{0}=$ covariance matrix for coefficients of R.E model $\left(b_{s}\right)$.

In Hausman test null hypothesis show fixed effect. In according above tests we run the regression whit fixed effect model (EGLS method). Table 3 presents the Panel EGLS (cross-section weights) regression results.

Table.3. Estimation of model (sample 2002-2009)

\begin{tabular}{lcccc}
\hline Variable & Coefficient & Std. Error & t-Statistic & Prob. \\
\hline Log GDP & 3.23 & 0.46 & 6.89 & 0 \\
Log Population (POP) & 6.19 & 0.85 & 7.26 & 0 \\
OPENNESS & 0.015 & 0.0046 & 3.32 & 0.0012 \\
Political Stability (PS) & -0.21 & 0.102 & -2.09 & 0.0381 \\
R-squared & & 0.94 & & \\
F-statistic & & 93.35 & & \\
Durbin-Watson stat & & 1.5 & &
\end{tabular}

\section{Conclusion}

Political stability is playing an important role in determining FDI in OIC Countries. There is direct relationship between political stability and FDI in this study. We have used a panel data regression model to study the impact of the Political Stability on FDI in OIC countries for the period 2000-2009. Our findings indicate there is a positive and significance relationship between foreign direct investment and gross domestic product, trade openness and population. Also the explanatory power of the model is high; that is, it can explain \% 94 of factors determining foreign direct investment. Our conclusion supports the detrimental impact of Political Stability on FDI. Therefore, in order to improve foreign direct investment policies to reduce Political Instability should be implemented in countries under consideration. However the role of international corporations via International Organization such as The World Bank and Transparency International should be taken into account.

\section{References}

Alesina, A., Ozler, S., Roubini, N. and Swagel, P. (1996): Political Instability and Economic Growth, Journal of Economic Growth, 1(2): 189-211.

Alesina, A., \& Perotti, R. (1996): Reducing Budget Deficits, Swedish Economic Policy Review, 3(1).

Amitendu, P., Shounkie, N. (2007): Technological Capability as a Determinant of FDI Inflows, Evidence From Developing Asia \& India, Working Paper, 11(193): 1-29.

Baltagi, B. (2008): Econometric Analysis of Panel Data, April, 4th Edition.

Barro, R. (1995): Inflation and Economic Growth, NBER Working paper.

Biglaiser, G., \& Brown, D. (2009): Political Stability and Foreign Direct Investment in Latin America, Paper presented at the annual meeting of the Western Political Science Association, 2009 from www.allacademic.com.

Busse, M., Hefeker, C. (2007): Political Risk, Institutions and Foreign Direct Investment, European Journal of Political Economy, 23: 397-415.

Fatehi S., k., \& Shafizadeh, H. (1989): The Association between Political Instability and Flow of Foreign Direct Investment, Management International Review, 11(29): 4-13.

Globerman, S., \& Shapiro, D. (2003): Governance Infrastructure and US Foreign Direct Investment, Journal of International Business Studies, 11 (34):19-40. 
Jafari S., A., Rezanejad, Z. and Ariani, F. (2010): Growth and FDI in OIC Countries, Australian Journal of Basic and Applied Sciences: 4883-4885.

Jafari S., A., \& Aryani, F. (2010): Governance and FDI in MENA Region, Australian Journal of Basic and Applied Science: 4880-4882.

Jakobsen, J., \& de Soysa, I. (2006). Do Foreign Investors Punish Democracy? Theory and Empirics, 19482001," Kyklos, 59(3).

Johnson, A. (2005): The Effects of FDI Inflows on Host Country Economic Growth: 1-5.

Kapuria, V. (2007): Economic Freedom and Foreign Direct Investment in Developing Countries, Journal of Developing Areas: 143-154.

Kobrin, S. (1979): Political Risk, a Review and Reconsideration, Journal of International Business Studies, 11 (10):67-80.

Li, Q. (2005): Political Violence and Foreign Direct Investment, Working paper, 11(143).

Loree, D. and Guisinger, S. (1995), Policy and non-Policy Determinants of U.S. Foreign Direct Investment, Journal of International Business Studies, 26(2): 281-299.

Sarisoy, G., \& Manzocchi, S. (2008): Political Regime and FDI from Advanced to Emerging Countries, forthcoming Review of World Economics: 1-24.

Schneider, F., \& Frey, B. (1985): Economic and Political Determinants of Foreign Direct Investment, World Development, 11(13): 161-175.

Younis, M. Lin, X., \& Sharahili, Y. (2008): Political Stability and Economic Growth in Asia. American Journal of Applied Sciences, 5 (3): 203-208.

Woodward, D. and Rolfe, R. (1993). The Location of Exportoriented Foreign Direct Investment in the Caribbean Basin. Journal of International Business Studies, 24(1): 121-144. 